\title{
Deformation Pianism Of Filament Improved Paving Girder: A Prevailing Retrospect
}

\author{
Jeremiah Horn, Daisy Celia \\ Department Of Civil And Environmental Engineering Berkeley University \\ California
}

\begin{abstract}
This paper reviewed emblematic discussion on behavior of concrete composite girder subjected to monotonic and cyclic loading as tentative analysis contributes through the analysis of the review. The main discussion is normally concerning the shear behavior of girders made-up of varied structural members, were tested at varied loading condition. Dissimilar volume fractions are utilized in the fibrous concrete girders of the take a look at program as she are in forcement.The use offers is especially engaging if conservative stirrups are often eliminated, that reduces reinforcement congestion. The fibers can make the failure mode additional ductile by increasing the enduringness of concrete. The literature accessible on girder has been extensively searched forgetting a platform for the begin of analysis on the behavior of concrete composite girder is deserted briefly. Finally, general last remarks are made along with potential suggestions for prospect directions of analysis.
\end{abstract}

Keywords: girder, Monotonic and Cyclic Loading, Shear Behavior, Fibers, Volume Fractions, Conservative Stirrups

\section{Introduction}

Pertaining to the shear failure of concrete members, it's documented that once principal tensile stresses exceed the tensile strength of concrete, diagonal cracks occur in the shear span, Chalioriset al(2011). The use of discontinuous, randomly oriented fibers has long been recognized to give post-cracking tensile resistance to concrete. Thus, their use as shear 
reinforcement in concrete (RC) girders has been the main focus of many investigations within the past four decades. In general 3 completely different failures modes to consider: flexural failure, flexural failure followed by shear failure, and abrupt shear failure while not shear failure. For the latter two cases comparatively small/dare concerned, and as half of the experimental program, material and structural take a look at square measure performed for the RC and SFRC girders below low-to high shear-to-moment ratios. The addition of fibers to a strengthened concrete girder is familiar to increase its shear strength and if sufficient fibers square measure additional, a brittle shear failure will be suppressed in favor of a lot of ductile behavior combination interlock is one in every of the most contributions to the shear strength of concrete members, it have found that the shear strength of prestressed Self-Consolidating Concrete (SCC) girders is slightly but that of prestressed normal concrete (NC) girders due to the smaller amount of combination used in the SCC. The performance of $2 \mathrm{RC}$ deep girders with massive openings below monotonically multiplied homocentric loading.

\section{Test Specimens}

Out of twelve girders of three hundred metric linear unit, 600 metric linear unit and 1200 metric linear unit overall depth, four girders of every size were tested. 2 different percentages of horizontal shear reinforcement were used particularly zero. $2 \%$ and $0.3 \%$ of the gross space of girder section. The grouping of girders is Series I, II, and III .Five specimens had no typical shear reinforcement (partially while not stirrups) whereas 2 girders had closed steel stirrups with diameter of eight metric linear unit at uniform spacing of two hundred metric linear unit for effective depth and therefore the length of the girder is 275 metric linear unit and 1600 $\mathrm{mm}$ respectively, the influence of the steel fibers on the shear response of concrete girders below monotonic loading and cyclic loading is experimentally investigated, the study contributes to the rather restricted existing on shear testing of fibrous concrete girders below cyclic deformations by Chalioriset al(2011). a complete of eighteen longwise ferroconcrete girders consisting of 9 girders manufactured from Scan 9of CVC were tested within the investigation.

\section{Discussions Of Result}


The initial diagonal crack was shaped at a stress of four.76 MP. The cracks were ascertained diagonally connation the support and the load purpose. Further, with the increase in the load, the diagonal cracks began to widen. At a stress bigger than eleven.38 MP a, several diagonal cracks were ascertained, that joined the support and also the load purpose at a stress of twelve.00 MP an alleged deliberate the massive size SCC moreover as CVC girders had additional variety of cracks compared to the smaller sized girders. The by experimentation ascertained initial diagonal cracking and final masses of 106.6 khan a hundred thirty five.9 ken severally area unit known within the load-deflection transmit of the girder. The SCC girders varied within the vary $83 \%-100 \%$ compared to the vary $76 \%-92 \%$ for the corresponding CVC girders. Diagonal cracks shaped within the shear span of the tested girders that exhibited shear failure. The applied numerous the crack breadth of the monotonically tested girders. The ultimate deflection of these girders at failure is additionally according as decreasing. In all the girders specimens, initiation of cracks was from all-time low of the girders.

\section{Summary And Conclusions}

There has been a non-negligible size result on the diagonal cracking of RC deep girders, in that as the girder depth increases from 600 millimeter to 1200 millimeter, the diagonal cracking strength is found decrease. terribly robust size result has been observed in RC deep girders on the final shear strength. concerning 35-55\% decrease in the shear strength was observed when the girder depth was exaggerated from three hundred millimeter to 1200 millimeter. The post-diagonal cracking shear resistance capacity(derived from combination interlock and fixing action) was comparatively lower in the SCC girders compared to the CVC girders. Based on the experimental result of steel fibrous girders, it will be deduced that fibrous girders showed overall shear performance since they exhibited exaggerated shear strengths, final deflections and energy dissipation capacities regarding to the corresponding non-fibrous control specimens. The behavior of the deep girders with massive openings that were designed exploitation immediate memory. To investigate the result of native strengthening on the load-transferring mechanism and failure modes of test specimens. To study the behavior of SFRC specimens and compare that the behavior with that of RC specimens designed exploitation STMs. A ductile plastic mechanism developed when the formation of many plastic hinges in specimen SFRC.Due to the changed strength exaggerated by the addition of fibers, PPFRC girders show increased shear strength and energy distribution capability. Thanks to the polypropene fibers, the shear stress of a fibrate in forced concrete girder increase, further mode, 
the failure product of the girder is modified to be a lot of ductile. The shear strength of PPFRC increase by eighty to eighty fifth duet addition of 1 Chronicles polypropene fibers that helps to cut back stirrups demand.

\section{Reference}

1.Appa Rao G., Influence of girder size and distribution of horizontal reinforcement on shear strength of RC deep girders'.

3. Shoo (2001), 'Shear behavior of longitudinal reinforced self-compacting concrete girders'.

4. Calories C.E and Safari E.F (2009), 'Shear performance of steel fibrous concrete girders'.

5.Chien-Hung statue maker and Jinn-Hung bird genus (2010), 'Shear behavior of Self Consolidating concrete girders'.

6. Shoo, Carlos A. Flores and Shih-Ho Chao (2011), 'Behavior of steel fiber-reinforced concrete deep girders with large opening'.

7. Hay H. Dinah, Gustavo J. Parra-Montesano's, and James K. Wight (2008), 'Shear behavior of steel fiber-reinforced concrete girders without stirrup in for cement. 